Petra Heyse

\title{
'SHE HAS TO BE PREPARED TO IMPROVE HERSELF': SHAPING FEMININITIES IN TRANSNATIONAL MARRIAGE AGENCIES IN RUSSIA
}

This article draws on a broader research project that scrutinizes online/offline representational practices on transnational matchmaking websites featuring so-called 'Russian brides'. The central research question is: how are recurrent online representations related to gender (in intersection with other identity categories) co-constructed in the daily interactions between matchmaking staff and female clients on the floor of a marriage agency. To these aims, the researcher conducted participant observation in a transnational marriage agency in a Russian city and used linguistic ethnographic methodologies. The analysis for this article concentrates on the routine argumentative strategies that are used by matchmaking personnel to legitimate their intermediating role to Russianspeaking female clients in the case agency on the basis of in-depth interviews with agency staff and female clients. The analysis of discursive positioning in interviews with translators and female clients sheds light on the social order that is discursively created. This order is functional in defining and reproducing the commercial dependencies between matchmaking staff and female clients in a transnational globalized industry. This study demonstrates the way in which: (a) matchmaking personnel in the case study constructs subject positions in discourse - i.e. of transnational matchmaking experts and of female clients - by drawing on commonsensical public discourses of difference that encompass gender, age and nationality, and (b) matchmaking personnel affiliates with its clients by conceiving the matchmaking approach as an increasingly popular genre of self-improvement for Russian-speaking women.

Keywords: linguistic ethnography, transnational matchmaking, ideology research, Russia, cultural stereotyping, case study

DOI: $10.17323 / 727-0634-2018-16-2-355-370$

Petra Heyse - Departement Taalkunde (IPrA Research Center), Universiteit Antwerpen, Belgium. Email: petra.heyse@gmail.com 


\section{Situating This Study in the Broader Research Project}

In international matchmaking, 'Slavonic femininity' has become a globalized commercial brand with well-defined characterizations (Vartti 2003; Luehrmann 2004; Johnson 2007). Matchmaking websites typically represent Russian-speaking femininity as a form of 'traditional womanhood', emphasizing qualities such as domesticity, family-orientation, high education, patience, tenderness, and beauty, evoking 'patriarchal images of a woman who knows her place yet is very sexy and hyper-feminine' (Patico 2010:38, 23). This article draws on a broader research project that scrutinizes online/offline representational practices on transnational matchmaking websites featuring socalled 'Russian brides'. In this project, I am not primarily interested in the content, and the effects of these online images on the stigmatization of Russian-speaking women in migration contexts, which has been dealt with extensively elsewhere (Johnson 2007; Flemmen 2008; Heyse 2010; Patico 2010). From a critical emancipatory research standpoint, I consider it necessary to gain an insight into this omnipresent, powerful stereotype reproduction, into the linguistic pragmatics of online matchmaking services, i.e. the how's and the why's of the continuous online regeneration of gender- and nationalitytypical discourses (in text and images) on so-called 'Russian brides'.

In the case of transnational online matchmaking, where partners have different national and linguistic backgrounds, an extra offline mediator that facilitates inter-linguistic and inter-cultural communication is often implied. In Russia, for example, local marriage agencies assist female clients in their interaction on transnational matchmaking sites. Therefore, it is likely to hypothesize that marriage brokers have privileged access to global ideologies on so-called 'Russian brides' on matchmaking websites and it is interesting to explore how these commercial brokers realize their gatekeeping position towards female clients in a context of greater accessibility of the Internet in Russia, and increasing alternatives to meet partners individually and free-ofcharge on a global scale. Thus, I look at how recurrent online representations related to gender (in intersection with other identity categories) co-constructed behind the screens, in the daily interactions between matchmaking staff and female clients on the floor of a marriage agency?

In previous articles, I explored representational strategies and adaptational routines in online self-advertisements on transnational matchmaking websites (Heyse Forthcoming-a, b). The present article focuses on social relations, and more precisely on positioning through discourse, through which practices of mediation between agency staff and female clients are facilitated and legitimated. How do both parties position themselves and others in 'an acceptable way', and how is the 'acceptable' constructed in discourse? This article explains how identification processes of female clients within online representations are meandered by matchmaking staff and realized through discursive 
positioning strategies, which always involve issues of authority and power. Underlying this is the theoretical premise in critical discourse studies that the 'commonsensical' is related with ideology and that certain groups in society have more power, i.e. that what they say is more commonly accepted as 'normal', 'unproblematic' and 'natural', and that they have privileged positions to reproduce, but also to change ideologies (Wodak 2006; Van Dijk 2006; Verschueren 2012). Actors with privileged access to mainstream media, such as the matchmaking personnel in this study, can be considered such a powerful group and it is necessary to analyze how they realize this position interactively.

It is important to note that this research does not intend to formulate certain characteristics of so-called 'Russian femininity'. The scope is broadened from what is observable on the screen to how practices are represented. I argue that differences are situated in representational routines, and not in the beings, and that these differences are ritualized in the daily argumentative practices of matchmaking staff, which are - mutually - shaped in accordance with the expectations of their audiences - that is, male and female matchmaking clients.

\section{Contributions to the Field}

Discursive studies on dating advertisements are mainly conducted in the West, focus on within-country dating (for exceptions, see: Patico 2010; Schaeffer-Grabiel 2005), and gender is included as the single pivotal category. The topic of cultural identity received limited attention in Computer Mediated Communication research (Baym 2012: 68). However, if the matchmaking context is transnational and the objective heterosexual partnership formation, discourses developing around gender- and nation/ethnicity identity dimensions are likely to arise. Therefore, transnational online matchmaking, in which people tend to formulate polarized opposite sex preferences that are signified with particular cultural meanings, offer excellent sites to study online stereotypical practices encompassing gender in intersection with other aspects of cultural identities.

Several studies in the volume on mass media and changing values in postsocialist Russia edited by Arja Rosenholm et al. (2010) illustrate that cultural products of entertainment have a decisive impact on the fashioning of identities and lifestyles, particularly in shaping gender relations. The authors argue that, in today's Russia, the media emerge as 'technologies of power that generate, adapt, cultivate and control life' (Ibid:6). Online matchmaking sites are such a form of influential media that are acknowledged to shape gender ideologies in Russian society (Luehrmann 2004). Various hypotheses on the mutual constitutive influences between online transnational matchmaking and offline societal gender ideologies have been formulated. In a 'mail-order-bride perspective', for example, which dominates policy circles, public debate and feminist research (e.g. Hughes 2001; Crandall et al. 2005), matchmaking web- 
sites featuring 'Russian brides' are problematized because they are hypothesized to impose a 'traditional' femininity upon Russian-speaking female matchmaking clients (Vartti 2003; Johnson 2007; Patico 2010). 'Poor women' are reduced to products of commodification that are bought by 'rich imperialist men' (Schaeffer-Grabiel 2005), thereby problematizing a patriarchal gender model of male buying power and female dependence. This line of reasoning assumes that women do not desire relations of dependency with men, and thus, are oppressed by matchmaking systems.

Underlying this stream of thought is a Western feminist ideal of female independence and equality. However, studies that collect ethnographic data with female matchmaking users in Russia invite us to question the desirability of Western feministic perspectives from the frame of reference of the women involved. Ethnographies by Jennifer Patico (2010), Petra Heyse (2010) and Sonja Luehrmann (2004) show that website discourses are not so alien from self-narratives produced by their women-users and that on both levels (individual and mass mediated) a general 'nostalgia for the traditional family' (Kliuchko 2011:21) seems to resonate:

In the mass media, in political and academic discussions, and even in documents of the women's movement, there is an emphasis on the increased social significance of the traditional female roles of wife and mother, the return to men of economic responsibility for providing for the family, the important role of a 'traditionally strong' family in processes of consolidation and revival of the nation, and the significance of the female reproductive function for strengthening the nation as a whole. It is paradoxical, but a return to the traditional family is seen as a strategy for renewing society. $<\ldots>$ The idealization of the traditional family presupposes distancing from communist experience and state-imposed formal egalitarianism, and a return to supposedly natural gender roles (Ibid:20).

Studies suggest that matchmaking industries attract clients by positioning their services as solutions to so-called 'gender systems in crisis' in both postsoviet countries and Western societies, and by offering members opportunities to take part in the 'transnational realm of alternate values' (Patico 2010:22). So far, however, it remains unclear how these 'crises' are translated and made operational in transnational matchmaking contexts. This article contributes by incorporating both parties at the same time - i.e. the industry and its users making it possible to explore how a company is profiling its services in a way that is acceptable from the frame of expectations and goals of female clients. It is only the study of discourses in context, particularly in their context of reception, and not only in their context of (re)production, that can help us to interpret gender, speech and power cross-culturally.

Social researchers on the 'new therapeutic culture' in post-Soviet Russia position online dating among a broad spectrum of techniques that profile themselves as sources for the organization of private life, including forms of 
therapy (group and individual), coaching, training, magazines, talk shows, and self-help books (Matza 2009; Salmenniemi 2010; Lerner 2011). The director of the case agency uses the label 'group-therapy' for the four-day training seminars that she organizes to instruct female Russian-speaking clients on how to interact with 'foreign men'. This research offers empirical insight into how the case company is creating possibilities for female clients to take part in these cultural resources that are found to become increasingly important in shaping subjectivities after the 'collapse of the symbolic order itself' that has marked the disintegration of the Soviet Union (Klingseis 2011:92).

\section{Methods and Analytical Preferences}

The overarching method has been participant observation of nine months (August 2012 - April 2013) as a 'translator' in one selected transnational marriage agency in a Russian city. ${ }^{1}$ For this article, I mainly use interviews with translators and female clients. The analytical focus in the data is on recurrent patterns of comparative and contrastive discourse, in which actors in this company relationally position themselves and others and ornament themselves and others with certain behaviors, roles, knowledge, capabilities and styles. This focus on the positioning of speakers (towards their discourse and towards others) is motivated by a theoretical view on language use as 'constitutive':

discourses do not just reflect or represent social entities and relations, they construct or 'constitute' them; different discourses constitute key entities (be they 'mental illness', 'citizenship' or 'literacy') in different ways, and position people in different ways as social subjects (e.g. as doctor or patients) (Fairclough 1992: 3).

Social positions and relations, in other words, are not given, but continuously negotiated in ongoing interaction. Moreover, it is through this positioning that speakers reproduce the social order.

I hope to make co-constructed and institutionalized relationships of interdependence between matchmaking staff and female clients visible, and pay particular attention to patterns of unquestioned meaning and ideologies that are inferred to legitimize own and others' positioning. In the interviews, I trace discursive markers and strategies such as evaluative language, terms of address, comparative language indexing boundaries (e.g. 'we-they', 'our-their'; 'Russia-Europe, West'; 'men-women'; 'here-there'), generalizing language (e.g. 'in general') and explanations (e.g. 'because')2

\footnotetext{
${ }^{1}$ For the sake of anonymity and informed consent, I cannot specify the name of the agency. Names of cities and other identifiable information are likewise anonymized.

${ }^{2}$ Readers interested in the Russian interview citations can contact me by email.
} 


\section{Results}

\section{Categories of 'translators' and 'clients'}

The working relation between translators and female clients in this agency is formally regulated by a contract that is signed by women upon registration in the agency. One passage in this contract specifies that translators will communicate in the name of female clients. In practice, this means that translators are authorized to work with female clients' profiles on the matchmaking sites this agency is cooperating with. Although there is rich variety in personal attributes, motivations and experiences in both client and translator groups, the general 'profile' of both groups and their particular interdependent positioning in the agency's working procedures can be interpreted as a confirmation of a social norm in Russia that women should marry at an early age, as articulated by a translator:

Let's consider a situation, in which a woman of 35-40 years, yes. If a woman is $35-45$ years, without children, then in Russia she has practically no chances left to find a husband who is willing to have a child from her. Because, for Russian standards a 40-years old lady, who is without children - is a kind of defect. This means that something is wrong with the woman. Therefore, well, her dream about a child cannot already be realized in Russia.

An 'age' divide in combination with a person's 'marriage history' seems to define subject positions and creates a difference between women who are considered to be in need of assistance (female clients) and women who still have all the chances and are positioned as 'experts' (translators). Translators in this agency are young girls, mostly students, with international language skills. Although the agency has female clients in all age ranges, the 'typical female client', according to translators, tends to be a woman above 30, with limited language skills, possibly with restricted experience or time constraints to engage in online dating, and above all, who seems to have lost her chances to find a partner in Russia. This is illustrated by the next quotation narrated by a translator, who is also dating with her own profile on the website in question, but claims not to take it seriously for herself. As she explains, the agency's services, the websites and the transnational marketplace are for a certain category of women to which she does not count herself (yet). She presents herself as a young girl, whose chances in the local marriage market are still guaranteed. From her more comfortable position she considers herself well-situated to help female clients:

$I$ : Then why are you doing it, if you consider that, that it's not realistic.

$R$ : Because, for some people it works, yes. I am very young, yes, I am 23 years old. And, maybe, when I get older, I can reconsider my opinion. If I know that, that's it, here I won't find anything, anyone, I will give it a chance, naturally.

I: To find someone here, yes? 
$R$ : Yes, in general for me, on paid dating websites, yes, where strange people are, I don't know. But women who, really, they have a family, they are working, they barely master English, they have no time to dedicate themselves to this, they won't engage in this seriously. Then we help them. Yes, and we, to my opinion, are really helping them then with their self-esteem. Women often have a low self-esteem. Because, even if we send them [female clients] only some men, if they can feel that men are interested, that is, you evoke interest in someone, in any case this will be helpful, even if she after all doesn't get married, but she will know, that people like her.

The underlying idea among agency staff that often surfaces in their talking about female clients is that women who enter the category of 'clients' have failed, did something wrong and lack the capabilities to interact with the opposite sex. Besides language knowledge and technological know-how, young girls are supposed 'still to know how to do it'. Among translators it is believed that foregoing negative relational experiences created defensiveness and toughness in female clients. Younger girls are supposed to be more romantic and less demanding with men, which indicates the kind of femininity that is desired in this heterosexual matchmaking context: 'Why do women need translators, like us, because we are capable of writing an adequate letter, to smoothen off the rough edges that she is writing sometimes'.

The supposedly more powerful position of translators over female clients in relation to their age is, however, not absolute. From the perspective of age hierarchy, it is more difficult for younger girls to express their opinion to a person higher in age. When addressing people of an older generation in Russia, politeness forms are expected, as exemplified by the use of patronymics. Observations from the field demonstrate that the working relation of translators and clients cannot be understood in binary, fixed terms. On the one hand, translators' control over female clients' communication can unmistakably be interpreted as the former's dominance over the latter. In order to maintain access to the expected services, female clients are held accountable to certain rules of etiquette in the cooperation with translators:

That a woman knows that she has to interact in a proper way with her manager [translator], because she [female client] to a certain extent depends on me, who I will find for her. Quarrelling is not done, elementarily. But not all of them are getting this.

On the other hand, translators are mutually dependent on female clients' participation in the practices of representation. Female clients are asked to provide personal information by means of a self-presentation letter and are requested to write answers (in Russian) to letters sent by men (translated into online messages in English by translators). Female clients' financial contributions are not directly connected with successful outcomes in the system, whereas translators' salaries are. Hence, the pressure to write according to system requirements is stronger for translators, and potentially creates tensions 
if women are not cooperating as expected by translators, such as answering immediately and providing answers to men's questions.

Furthermore, the relationship of asymmetry between agency staff and female clients is solicited, since clients deliberately address the agency as an expert from a position of advice-seeker. Although the techniques and discourses often appear coercive for me as a researcher, female clients I interviewed report being in need of this clear guidance and appreciate being taken by the hand by an expert who instructs them on what to do. Most of the clients interviewed got to know the agency through positive word-of-mouth from other clients. Interviewees report that these services, in particular a training seminar ('Bride School') and self-help tutorial written by the company's director, contribute to the credibility of the company and female clients' feeling of being 'prepared' and 'protected' by the agency and its staff. The clients in the next quotation locate the agency in the area of training and self-improvement techniques, and consider the company's approach as less commercial -i.e. less oriented towards gaining money:

$R 1$ : ...school of flirting, you see...

I: And, a school for flirting... These exist, yes?

R1: We have them, they exist. Many. And schools... all kinds of seminars on femininity, like, how to conquer a man, how to find a millionaire, how to win the heart of a prince...

$R 2$ : The ones that deliver easy distractions from life, you understand?

I: Yes.

$R$ : They are not... not... Not so, probably, say realistic... not... not... [director's name] you see, for me... it's realistic. And that is her big merit. Yes. Moreover, she also gave us her book, to all of us [participants of the schools]. That is, she has put it there, yes. That is additionally like an original-model, additionally. That is... Therefore, the agency - is a big help, really for a person.

In this quote, the clients express particular satisfaction with the person of the director as an expert, who builds her discourse around anecdotes - which contributes to her aura of expertise - and who continuously constructs characters in her narratives with whom clients can identify. This likewise encourages clients to become involved in one of the stories themselves.

\section{Precondition to become a 'client': Being primed to situate responsibility in oneself}

A common feature of self-help techniques is that 'social problems are psychologized and treated as individual "failures" caused by an undeveloped self' (Salmenniemi 2010: 139). Self-help techniques foster a desire for self-realization and, hence, produce 'a wide variety of un-self-realized and therefore sick people' (Illouz 2007: 47): 'the narrative of self-help is thus not only closely 
intertwined with a narrative of psychic failure and misery, but is actually put into motion by it' (Ibid: 48).

In the case agency, talk about the deficiencies of (Russian) men by female clients tends to be disproved by agency staff. Female clients are required to critically evaluate themselves instead of blaming the other, in this case 'Russian men'. The precondition for obtaining results in the matchmaking processes of this agency, it is argued, depends on the will of female clients, their preparedness to improve themselves and to identify with femininities that are promoted by the company. In this line of argumentation, the director seems to deconstruct the differences between Russian and Western men, arguing that 'everywhere men are the same'. Marriage with a Westerner cannot be expected to be a solution to one's problems, as is (was) generally believed among women, the director claims; in order to realize change, women need to situate the problem and path to a solution in themselves:

This was a commonly spread idea to a lot of women before, now to a lesser extent. The belief, that if it's a foreigner, that it means he's decent, because he's a foreigner. This means that foreign men are given more credits, they are thought of as, well, once he's a foreign man, means that... Well, he's not that kind, like Russian [man], it means he's not like that. But he actually is like that.

The subject-position that a self-help methodology aims to construct - a positive, active subject, that is ready to engage in long-term work on their selves (Salmenniemi 2010) - appears to be profitable for this business context. The 'search' is discursively framed by agency staff as an 'active search', in the sense that female clients are challenged to become visible on the online market and have to devote themselves to the quest for men's attention. The director strategically involves female clients in this competitive marketing logic by aligning with them during the seminars and framing the 'search' as a common endeavor ('our search'):

Therefore, in any case, how hard you try, in any case you have to... The position 'I am so wonderful, and you have to love me the way I am' is... Undoubtedly, of course, each of us is unique. We are all wonderful. Undoubtedly, there is a person who can estimate this at its true worth. But, it's simply possible to do something on yourself and to speed-up a meeting with this man of your dreams. Or it's possible to sit, ehm, on your butt, to wait, and nothing happens. Well, in principle, my point of view is, that (.) our search is, as a matter of fact, I would say, active. And the activity of this search, that is, the quicker attraction of gentlemen, begins with... the one that has to happen fast. This, of course, starts with you in your heads.

However, the kind of activity that is required seems to conflict with female clients' gender-normalized expectations. Women are stimulated to take the first step (that is: accept that presentation letters are sent out of their names). A translator explained that women generally expect that men will initiate courtship. The agency's discursive strategy to conquer female clients' comfort 
zone is by making them partners in dealing with a 'common threat,' that is labeled as 'competition' and legitimized by giving this 'competing other' a human face. In instances where female clients' active contribution is discussed, translators tend to refer to the 'competition of Ukrainian girls':

Ukraine has played a bad role in this. Ukraine, she distinguishes herself from us in, ehm (.) if you will look at any kind of dating website, if it is Ukrainian. Pay attention that Ukrainian pictures are always MORE erotic. I would say, they are SUPER-MEGA erotic. Girls, in general very young, with long legs, half-naked. That is, as a matter of fact, the same sex that... To which many man are still attracted. In Ukraine, they created from the marriage business just business.

The category 'Ukrainian girls' is associated by agency personnel with characteristics such as 'beautiful, very young, naked, extravagant'. First, this categorization should stimulate female clients' required instigating and purposeful position in the mediational processes. Second, it serves as an antidote against which the construction of a desired kind of femininity, with which female clients are likely to identify, is constructed: a well-taken-care-of, groomed, natural kind of femininity that gives off a sense of 'realness'. Third and related, the nationality dimension is used to draw lines between trustworthy and deceitful business practices.

The femininity promoted in this agency is linked with the self-profiling of the company in the transnational matchmaking market: a credible agency, working with 'real profiles' that is mediating serious long-term heterosexual partnerships. Matchmaking services promoting Russian-speaking women have a controversial reputation in public, media and academic debates and are often closely associated with trafficking for the sex trade and with prostitution (e.g. Hughes 2001). 'Ukrainian girls' and 'Ukrainian marriage agencies' are blamed for the industry's bad reputation and suspicion among male clients. The absence of argumentative efforts to motivate these nationality-stigmatizing expressions, i.e. the unquestioned acceptance of the identification of this category with certain fixed and pejorative characteristics, indicates that these discursive instances are situated in broader ideologies on gender and nationality.

In this field, the inference of 'Ukraine' as the more generally accepted 'inferior, deceitful other' has to protect the reputation of the company, female clients' identification processes within this contested industry, and the moral integrity of the personnel working in this company:

Men [registered on the websites] are blaming women. They are expecting bad from us [women on the websites]. They often get cheated by Ukrainian women on the websites, and so they are expecting this [to be deceived], and eventually, it turns out that they often get cheated. Some [of the men] think that they will arrive here and expect that they will immediately be taken into the bed. See, immediately, just, from the plane and directly to the bed. Women don't need this, we are not going to engage in prostitution here. We have another kind of work. This is not really a nice thing. 
The argumentation strategy can be connected with what has been identified as generally stigmatizing discourse practices on Ukraine that have proliferated in Russian society since the new political divisions between Russia and Ukraine (Morgunova 2011).

\section{Performing a desired kind of femininity}

\section{Culturalising femininity \\ in Russian/European institutions and education}

Desired images of femininity are not solely constructed in dialectics with what has been pointed at as 'Ukrainian women'. Consistent with previous research on transnational partnership of Russian-speaking women, agency staff is making systematic comparisons between binary categories of 'man', 'woman', 'Russia' and 'West' (and related categories such as 'foreign', 'Europe', 'America', or specific European countries and their adjectives), creating a contrasting and essential 'Russian' and 'Western femininity' (and 'masculinity'). The following excerpt in the self-help book of the agency's director, that is part of a lengthy argument that lists the reasons for 'Western men' to search for a 'Russian wife', illustrates how an approved 'Russian femininity' is contrasted with an undesirable 'Western femininity':

Western women are more exigent, less capable of reaching compromises. Many Western women are career-oriented, stable relationships and children are becoming obstacles in their way to professional success. $<\ldots>$ Western women are not willing to give birth. First, they study, enjoy their life and work, and children - are a hindrance, a restriction to personal freedom. $<\ldots>$ A Russian woman in the understanding of foreign men is: kindness, understanding, coziness in the house - readiness to compromises, desire to have a family - orientation towards mutual understanding - good education and intelligence - closeness in mentality - boundless love for children - care and warmth - rational approach towards difficulties - capability to adapt to another country. Unfortunately, not all Russian women conform to this description, but the opinion remains intact.

The content of these contrasting discourses has extensively been studied (Johnson 2007; Flemmen 2008). This study contributes by showing how these differences are 'done' and are essentialized behind the websites' screens. In her book and during the school for brides, the director stabilizes the differences between 'Russian' and 'Western' women by situating them in the distinctive educational and socio-institutional contexts in Russia and 'the West'. Women in Europe, the director explains, can count on social benefits and prefer to be single (mother) instead of engaging in durable relationships:

The social support oriented towards women by the government is so strong that it is often more profitable for women to stay alone or as a single mother, than to connect oneself in a stable relationship. 
In a personal interview, the director uses the term 'gendered education' to signify the education according to a patriarchal family ideal in Russia, in which men - first fathers and later husbands - are supposed to be the heads of the family. Being educated like this, girls, and later women, expect to be located 'behind a man'. Here, she refers to etymology to demonstrate the cultural rootedness of gender imparity in Russian society. The expression for 'being married' in Russian (zamuzhem), the director argues, literally means 'behind the man.' In her explanation to female clients during the schools, she gesticulates this position by pointing with her finger behind her back:

...in principle, in Russia it is normal to have a man-breadwinner. It's normal, it's desired, we really want to hide behind someone's back. And I always explain that... In Russian language the word 'married'l signifies 'there' [points behind the back], you see 'there, behind the back'. Yes, maybe, half a step, maybe somewhere about, about half a stair, we, you see, there, see, want to be [shows with the finger behind the back]. And we have been educated this way. That, papa is principal in the house. See, 'papa comes, I will tell papa about everything!' [shakes her finger, imitates a mother] Yes? See, that is... And, there's no arguing with that.

She situates the foundation in childhood and therefore is implying a 'natural', unchangeable and unavoidable nature of gendered positions and behaviors in Russian society.

\section{From a 'failed subject' to a self-improving 'smart woman'}

After the discursive construction of an essential 'Russian femininity' that is desired by foreign men, the director problematizes that not all Russian women comply with this ideal. She is not directly addressing female clients during the seminars, but indirectly, by situating the cause of the problem in the plausible absence of a 'desired education', that is, education according to a patriarchal family ideal. Girls who are raised without a father, the director assumes, are likely to inherit the negative attitude towards men by their (disappointed) single mothers. Agency staff explain that this negative attitude and the assumed exigent nature of single women is the reason for female clients' relational failures. It is likely that many female clients feel addressed by this hypothesis. In a personal interview, the director more explicitly situates the incapability to communicate with men in female clients:

Because, sometimes, if they [female clients] come to the school for brides, and if they start to tell how they are communicating with men, simply makes the hair stand up on the back of the head. This makes them [men] to run to their places, all of them, either one. Anyone, even the blind, the mute, the deaf.

\footnotetext{
${ }^{1}$ The word zamuzhem springs from Church Slavonic Grammatica where it signifies 'the wife follows the man in marriage'. The word muzh in Russian means husband and the prefix za signifies - in this context - behind. Married status for men in Russian is indicated with a different word, namely zhenat.
} 
This problematized 'loss of femininity' in female clients and the identified symptoms such as independence, dominance and exigency seem to blur the constructed boundaries with the essential characteristics that were associated with the category of 'Western women':

$R$ : ...femininity in the understanding of the female role in the family. Simply, this, everyone [every woman] has this as a matter of fact, it seems to me, absolutely at anyone, even if you know what is right, and anyhow at a certain moment the mouth opens on an undesirable moment. See, and sometimes it's necessary to close it and just to keep silent.

I: And do you see in this respect differences between women here in Russia and in Europe? Because...

$R$ : You will not close a European woman's mouth. A European woman says everything what she considers to be necessary. And a Russian woman, a smart one, who wants to keep her family, who fights for her husband, will close her mouth and keep silent.

After creating the conditions for female clients to identify with this 'failed subject', the director abstracts a subject that is capable of changing this undesirable situation, the so-called desirable category of a 'smart woman', who is ready to improve herself and to be instructed in how to communicate with the category of 'normal men'. During the seminars, the director represents and performs feminine communicative behavior that she claims to be a condition to find a 'normal man':

A smart woman understands that in her case something with men is not working out, well, I mean, if only just to go to some seminar, to read some kind of book, to analyse. About, maybe, it's necessary to communicate with men in a different way. If only to change the intonation, yes, and all these: 'you have to, you need to'. He doesn't need and he's not obliged. If you want something of him, then you need to ask, and not demand it. Therefore, any normal man, see, normal man with his testosterone, if she will say 'you have to', he will say 'you go to.... Yes, he just sends her and he will do nothing for her. Men only understand, see: [tender voice] 'dear, it would be not bad, if you could for me, please, see do this and this and this'. And this I try to explain during the school. Because, to me it seems that, with any man, no matter his nationality, country, if they are talked with kindly, tender and through 'dear', you will reach much more than if you will stamp with your heels on... with your fist on the table and by raising some demands. Many women don't have this. See exactly, well, exactly no femininity.

The desired femininity constructed by the agency's director as a tender, dependent and permissive kind of femininity, who ideally reproduces women's more subordinate position in relation to men through a 'feminine speech style'.

\section{Conclusion}

The case study enables to observe how globalized and macro societal imaginaries of gender and the nation are adopted and strategically used for the 
benefits of the company: gender polarization and an idealization of patriarchal family relations to promote an essentialized femininity, and ethnic polarization with Ukraine to increase the credibility and trustworthiness of the own company. The analysis of discursive positioning in interviews with translators and female clients sheds light on the social order that is discursively created. This order is functional in defining and reproducing the commercial dependencies between matchmaking staff and female clients.

The analysis of self- and other positioning in the talk of matchmaking staff and female clients generates understanding of the multidimensional and situational character of power relations, and the many interdependencies between 'both parties'. By incorporating 'both parties' simultaneously, their understanding of each other and their mutual expectations, it is possible to counterbalance fixed and unidirectional interpretations of power. Matchmaking services, particularly offline intermediaries that facilitate online communication of clients (customers) in transnational contexts, position themselves and are interpreted as a type of 'self-help'. In these contexts of institutionalized advice-giving and taking, in which translators position themselves and are positioned by female clients as 'experts' in courtship interaction with foreign men, power is generally solicited, and it seems more appropriate to frame relations in terms of 'authority'.

The company is not developing its services in isolation, but offers services that are responsive to detected customer desires in the market. Yet, as commercial industries do, the company also tries to be ahead of needs, to create them and/or enlarge female clients' wants. The analysis demonstrates that the reasons why female clients approach the company are commercially exploited by company members, who are legitimizing their own intermediary position by discursively creating greater distances in the market: by cultivating cultural differences, utilizing stereotypes, by deepening female clients' selfperception of having failed with men and enlarging their need for assistance and techniques for self-improvement.

\section{References}

Baym N. K. (2010) Personal Connections in the Digital Age. Cambridge: Polity Press.

Crandall M., Senturia K., Sullivan M., Shiu-Thornton S. (2005) 'No way out' Russian-speaking Women's Experiences with Domestic Violence. Journal of Interpersonal Violence, 20 (8): 941-958.

Fairclough N. (1992) Discourse and Social Change. Cambridge: Polity Press.

Flemmen A. B. (2008) Transnational Marriages: Empirical Complexities and Theoretical Challenges. An Exploration of Intersectionality. Nordic Journal of Feminist and Gender Research, 16 (2): 114-129. 
Heyse P. (2010) Deconstructing Fixed Identities: An Intersectional Analysis of Russianspeaking Female Marriage Migrants' Self-representations. Journal of Intercultural Studies, 31 (1): 65-80.

Heyse P. (Forthcoming-a) Between 'Forwardability' and 'Authenticity': Writing Style as a Commercial Asset in Mediating Communication on Transnational Dating Websites. Journal of Pragmatics.

Heyse P. (Forthcoming-b) 'Russian Ladies looking for Western men'. An Analysis of Online Matchmaking Discourse from behind the Scenes. C. Timmerman, N. Clycq, F. Levrau, L. Van Praag (eds.) Imaginaries and Recognition as Key Concepts in the Changing Migration-Integration Nexus - An Anthology of Multidisciplinary Insights from the Flanders case. Leuven: Leuven University Press.

Hughes D. (2001) The 'Natasha' Trade: Transnational Sex Trafficking. National Institute of Justice Journal, (246): 9-14.

Illouz E. (2007) Cold Intimacies. The Making of Emotional Capitalism. Cambridge: Polity Press.

Johnson E. (2007) Dreaming of a Mail-Order Husband. Russian-American Internet Romance. Durham: Duke University Press.

Klingseis K. (2011) The Power of Dress in Contemporary Russian Society: On Glamour Discourse and the Everyday Practice of Getting Dressed in Russian Cities. Laboratorium, (1): 84-115.

Kliuchko O. I. (2011) Gender Stereotyping in Studying Pressing Social Problems. Russian Social Science Review, 49 (1): 75-91.

Lerner J. (2011) TV Therapy without Psychology: Adapting the Self in Post-soviet Media. Laboratorium, (1): 116-137.

Luehrmann S. (2004) Mediated Marriage: Internet Matchmaking in Provincial Russia. Europe-Asia Studies, 56 (6): 857-875.

Matza T. (2009) Moscow's Echo. Technologies of the Self, Publics, and Politics on the Russian Talk Show. Cultural Anthropology, 24 (3): 489-522.

Morgunova O. (2011) 'Borders become us': Russian-Ukrainian Dialogue in the Diaspora. National Identity in Eurasia II: Migrancy \& Diaspora, conference, 10-12 July 2009, Wolfson College, University of Oxford.

Patico J. (2010) Kinship and Crisis: Embedded Economic Pressures and Gender Ideals in Postsocialist International Matchmaking. Slavic Review, 69 (1): 16-40.

Rosenholm A., Nordenstreng K., Trubina E. (eds.) (2010) Russian Mass Media and Changing Values. London: Routledge.

Salmenniemi S. (2010) In Search of a 'New (Wo)man'. Gender and Sexuality in Contemporary Russian Self-help Literature. In: A. Rosenholm, Nordenstreng K., Trubina E. (eds.) Russian Mass Media and Changing Values. London: Routledge: 134-155. 
Schaeffer-Grabiel F. (2005) Planet-Love.com: Cyberbrides in the Americas and the Transnational Routes of U.S. masculinities. Signs, 31 (2):331-356.

Van Dijk T.A. (2006) Ideology and Discourse Analysis. Journal of Political Ideologies, 11 (2): 115-140.

Vartti R. (2003) Equal Partners Online? German Matchmaking Websites and Trafficking in Women. In: M. Morokvasic, U. Erel, K. Shinozaki (eds.) Crossing Borders and Shifting Boundaries. Wiesbaden: VS Verlag für Sozialwissenschaften: 177-206.

Verschueren J. (2012) Ideology in Language Use: Pragmatic Guidelines for Empirical Ideology Research. Cambridge: Cambridge University Press.

Wodak R. (2006) Critical Linguistics and Critical Discourse Analysis. In: J-O. Östmann, J. Verschueren, E. Versluys (eds.) Handbook of Pragmatics, Vol. 10, Amsterdam: John Benjamins Publishing Company: 1-24. 